\title{
Climate-driven shifts in continental net primary production implicated as a driver of a recent abrupt increase in the land carbon sink
}

\author{
Wolfgang Buermann ${ }^{1}$, Claudie Beaulieu ${ }^{2}$, Bikash Parida ${ }^{3}$, David Medvigy ${ }^{4}$, George J. Collatz ${ }^{5}$, Justin Sheffield ${ }^{6}$, and \\ Jorge L. Sarmiento ${ }^{4}$ \\ ${ }^{1}$ Institute for Climate and Atmospheric Science, School of Earth and Environment, University of Leeds, \\ Leeds LS2 9JT, UK \\ ${ }^{2}$ Ocean and Earth Science, National Oceanography Centre Southampton, University of Southampton, \\ Southampton SO14 3ZH, UK \\ ${ }^{3}$ Civil Engineering Department, Shiv Nadar University, Dadri, 203207 UP, India \\ ${ }^{4}$ Atmospheric and Oceanic Sciences Program, Princeton University, 08540 Princeton, New Jersey, USA \\ ${ }^{5}$ National Aeronautics and Space Administration, Goddard Space Flight Center, 20771 Greenbelt, \\ Maryland, USA \\ ${ }^{6}$ Department of Civil and Environmental Engineering, Princeton University, 08540 Princeton, \\ New Jersey, USA \\ Correspondence to: Wolfgang Buermann (w.buermann@leeds.ac.uk)
}

Received: 6 August 2015 - Published in Biogeosciences Discuss.: 25 August 2015

Revised: 22 February 2016 - Accepted: 25 February 2016 - Published: 15 March 2016

\begin{abstract}
The world's ocean and land ecosystems act as sinks for anthropogenic $\mathrm{CO}_{2}$, and over the last half century their combined sink strength grew steadily with increasing $\mathrm{CO}_{2}$ emissions. Recent analyses of the global carbon budget, however, have uncovered an abrupt, substantial

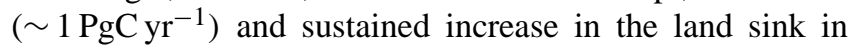
the late 1980s whose origin remains unclear. In the absence of this prominent shift in the land sink, increases in atmospheric $\mathrm{CO}_{2}$ concentrations since the late 1980s would have been $\sim 30 \%$ larger than observed (or $\sim 12$ ppm above current levels). Global data analyses are limited in regards to attributing causes to changes in the land sink because different regions are likely responding to different drivers. Here, we address this challenge by using terrestrial biosphere models constrained by observations to determine if there is independent evidence for the abrupt strengthening of the land sink. We find that net primary production significantly increased in the late 1980s (more so than heterotrophic respiration), consistent with the inferred increase in the global land sink, and that large-scale climate anomalies are responsible for this shift. We identify two key regions in which climatic constraints on plant growth have eased: northern Eurasia ex-
\end{abstract}

perienced warming, and northern Africa received increased precipitation. Whether these changes in continental climates are connected is uncertain, but North Atlantic climate variability is important. Our findings suggest that improved understanding of climate variability in the North Atlantic may be essential for more credible projections of the land sink under climate change.

\section{Introduction}

The world's land ecosystems act as a major sink in the contemporary global carbon cycle and, hence, alleviate the rise of atmospheric $\mathrm{CO}_{2}$ concentrations from global $\mathrm{CO}_{2}$ emissions and as a consequence climate change (IPCC, 2013). Yet, while critical for society our present understanding of the evolution of the land carbon sink under global change is still severely limited (Le Quéré et al., 2009). This is in part because multiple complex factors can influence the carbon balance of terrestrial ecosystems, including climate change, land-use and land-cover change (forest regrowth, 
fire suppression etc.), nitrogen deposition, and $\mathrm{CO}_{2}$ fertilization (Ciais et al., 2013). In this regard, it has been well documented that the land carbon sink (typically inferred as the "residual" in the global carbon mass balance of fossil fuel and net land-use-change (LUC) emissions, the atmospheric $\mathrm{CO}_{2}$ growth rate and oceanic uptake) is quite variable at decadal timescales (Denman et al., 2007). But in recent global carbon budget (GCB) studies with longer ( last 5 decades) and annually resolved records a rather abrupt, substantial $\left(\sim 1 \mathrm{PgC} \mathrm{yr}^{-1}\right)$ and sustained strengthening of the residual land carbon sink in the late 1980s has been identified (Sarmiento et al., 2010; Beaulieu et al., 2012a). Our overall confidence in this prominent shift, however, is somewhat limited since the residual land sink is the most uncertain term in the GCB. This is because uncertainties embedded in the individual budget terms (e.g., LUC emissions and oceanic uptake) propagate into estimates of the residual land carbon sink (Le Quéré et al., 2013).

Here, we explore if there is further independent evidence of a late-1980s regime shift in the land carbon sink through analyzing carbon fluxes from biospheric models of various complexity and observational constraints (e.g., satellitebased vegetation activity). Our emphasis is on global patterns of net primary production (NPP) since this key carbon flux is known to be a robust driver of carbon sink variability (Luyssaert et al., 2007; Zhao and Running, 2010). A particular focus is on identifying which land regions may have contributed to the potential shift and what underlying mechanisms may have caused it. Specifically, we analyze datadriven NPP data based on an established satellite-constrained biogeochemical model as well as process-based NPP data from nine terrestrial biosphere models that participated in a recent model intercomparison project "trends and drivers of the regional-scale sources and sinks of carbon dioxide (TRENDY)" (Sect. 2).

\section{Methods}

\subsection{Data and models}

We analyze temporal patterns in various metrics of the terrestrial carbon cycle based on three independent data sources. First, we analyze data-driven NPP fields based on simulations with the satellite-constrained biogeochemical Carnegie-Ames-Stanford Approach (CASA) model (van der Werf et al., 2006) for the period of available satellite vegetation data 1982-2011 (Zhu et al., 2013). This updated and extensively validated model runs at a $0.5^{\circ}$ spatial resolution on a monthly time step. NPP is a measure of the amount of carbon fixed by plants during photosynthesis and accumulated as biomass. The CASA model is conceptually relatively simple, and a number of potentially important processes and mechanisms, such as ones related to nutrients (e.g., carbon and nitrogen), are not considered explicitly (van der Werf et al., 2006). However, factors that influence vegetation productivity may be indirectly captured through the satellite-based fraction of available photosynthetically active radiation absorbed by plants (fAPAR), a key driver in the NPP CASA light use efficiency parameterization (van der Werf et al., 2006). This is demonstrated by two recent studies showing that trends in satellite-based vegetation cover are consistent with expectations of growth enhancement via the $\mathrm{CO}_{2}$ fertilization effect (Donohue et al., 2013; Los, 2013). Yet there is also new evidence suggesting that in densely forested ecosystems (tropical rainforests) fAPAR may not be fully responsive to the $\mathrm{CO}_{2}$ fertilization effect (Forkel et al., 2015). Temporally varying driver data used for the CASA simulations include, in addition to satellite-based fAPAR (fAPAR3g) (Zhu et al., 2013), also land temperature (CRU TS3.21) (Harris et al., 2014) as well as precipitation and surface solar radiation. We pay particular attention to uncertainties in these observationally based data sets and corresponding effects on NPP estimates. While land surface temperature data are considered to be relatively robust, a substantial limitation is that presently only one consistent satellite fAPAR data set exists that covers the last 3 decades (Zhu et al., 2013), which we consider a minimum record length for meaningful change point analysis. Nonetheless, to account at least partially for observational uncertainties, we evaluated different data sources for precipitation and surface solar radiation, which are known to have substantial uncertainties (Wild, 2009; Greve et al., 2014) (see Methods in the Supplement). Based on a final selection of driver data sets (one fAPAR, one temperature, three precipitation and three solar radiation; see Table S4 in the Supplement) we performed multiple CASA simulations with all possible input combinations (a total of 9 simulations) and analyzed the NPP ensemble mean with our change point methodology. We used the spread in these simulations as a measure of "observationally based" uncertainty. In a complementary analysis, we also analyzed the heterotrophic respiration $\left(R_{\mathrm{h}}\right)$ and net ecosystem production (NEP; estimated as NPP $-R_{\mathrm{h}}$ ) ensemble means from these sets of CASA simulations. Owing to the lack of consistent fire observations for our study period 1982-2011 (e.g., the Global Fire Emissions Database (GFED) era starts in 1997; see van der Werf et al., 2006), corresponding effects on variability in NPP and NEP were not considered. To ensure that the carbon pools are at steady state, the CASA model was spun up for 250 years using a driver climatology based on the study period 1982-2011.

Second, we analyze a GCB for the period 1959-2011 and consisting of $\mathrm{CO}_{2}$ emissions from fossil fuel burning and cement production as well as net LUC emissions, atmospheric $\mathrm{CO}_{2}$ growth rates and oceanic uptake (Le Quéré et al., 2013). Uncertainties in these budget terms are also provided and utilized to estimate uncertainties in net land uptake and the residual land sink (through the sum of squared errors).

Third, we analyze process-based NPP, $R_{\mathrm{h}}$ and NEP data based on ensembles of nine single terrestrial biosphere mod- 
els that participated in the recent TRENDY model intercomparison project (Sitch et al., 2015). Compared to CASA, the TRENDY models are substantially more complex and also run at significantly shorter time steps to resolve the diurnal cycle needed when coupled within Earth system climate models (Sitch et al., 2015). An important distinction is that in the TRENDY models vegetation characteristics (e.g., fAPAR) are simulated prognostically (unlike in CASA, where such information is inferred from satellite observations). In the TRENDY experiments (Sitch et al., 2015) the models were driven with observed climate and atmospheric $\mathrm{CO}_{2}$ data (S2 experiments) as well as with observed atmospheric $\mathrm{CO}_{2}$ data only ( $\mathrm{S} 1$ ), and, in order to isolate the variability due to climate, the difference between these two experiments (S2-S1) was taken. We analyze the NPP, $R_{\mathrm{h}}$ and NEP ensemble means (based on anomalies) from the nine participating models (Community Land Model 4CN, Hyland, Lund-Potsdam-Jena (LPJ), LPJ-GUESS, ORCHIDEE, ORCHIDEE-CN, Sheffield-DGVM, TRIFFID and VEGAS; for model details see Sitch et al., 2015) and used the spread among them as a measure of "model-based" uncertainty in our change point framework. Based on a recent comprehensive evaluation against observations, it was found that most of the TRENDY models are capable of simulating the shortand long-term first-order dynamics of the terrestrial carbon cycle (Piao et al., 2013).

\subsection{Statistical methodology}

We apply a consistent change point methodology on the various metrics of the terrestrial carbon cycle to identify patterns of regime shifts (characterized as abrupt, substantial and sustained changes) and to contrast them with patterns showing either no or more gradual changes. We thus determine in a first step the statistical model that best fits the time series under investigation based on three options: (1) a constant mean, (2) a shift in the mean and (3) a linear trend. While there are numerous alternative statistical models (e.g., shifting trends as seen in satellite vegetation data at local to regional scales; Piao et al., 2011), our choice of these three models is based on our primary objective to identify large-scale patterns in global and continental carbon fluxes that would be consistent with the recently observed regime shift in the land carbon sink (Sarmiento et al., 2010; Beaulieu et al., 2012a).

In the "shift-in-the-mean" model, the shift is located through a change point detection algorithm that includes discrimination against a trend and the background autocorrelation (red noise) by considering all positions in a time series as a potential change point from 5 to $n-5$, with $n$ being the record length (Beaulieu et al., 2012b). In a previous study, we found that, by restricting the search for change points in this manner, detection of spurious shifts at the beginning or end of a series can be avoided (Beaulieu et al., 2012a). In the change point method applied here, we also further developed the Beaulieu et al. (2012b) methodology to account for known explicit uncertainties in the time series under investigation. One important limitation here is that this statistical change point model cannot distinguish between a rather drastic shift (e.g., change from one year to the next) and a smoother shift over the span of several years. Adding additional parameters could in principle provide more information on the nature of the shift (e.g., smooth vs. abrupt), but this would also make the model prone to overfitting given the rather short time series in this study.

The most likely model among the three statistical models fitted is determined based on the Schwarz information criterion (SIC), which compares their likelihoods with a penalty for the number of parameters fitted. If the shift-in-the-mean model seems the most likely, we calculate in a second step the direction and magnitude of the shifts (subtracting means prior to and after the shift) and the corresponding $P$ value by integrating the full uncertainty of the data using Monte Carlo simulations. To perform the Monte Carlo simulation, we draw 1000 normally distributed synthetic series having the same statistical properties as the time series of interest. A new feature is that the series are simulated with uncertainty additivity: the squared variance of each data point is added to the overall time series squared variance, and the square root of this sum provides the synthetic series variance. This therefore takes into account the explicit uncertainties in the various time series under investigation. The change point method is applied to the synthetic time series, and a SIC difference between the model with a shift in the mean and no shift is calculated for each time series. This provides a distribution for the SIC difference under the hypothesis of no shift in the mean. The $P$ value is the estimated probability to find a SIC difference at least as extreme as the one observed, under the hypothesis of no change. This methodology assumes that the errors of the model are independent and normally distributed with a constant variance. We test normality of the residuals using the Lilliefors test, the independence is verified using the Durbin-Watson test and the constant variance is verified using a Fisher test. All tests are available and performed using MATLAB. If independence is not respected, we generate synthetic series with the same first-order autocorrelation as observed in the respective time series residuals.

\section{Results}

\subsection{Shifts in data-driven NPP}

Applying our change point methodology (Sect. 2.2) on datadriven global NPP fields reveals a marked spatial clustering of abrupt and sustained increases in NPP across northern Eurasia and northern Africa in the late 1980s (Fig. 1). At more regional levels, the impact of severe disturbance events such as the mountain pine beetle outbreak in the late 1990s in the temperate and boreal forests of western North America (Kurz et al., 2008) is also disclosed (via rapid and sustained 

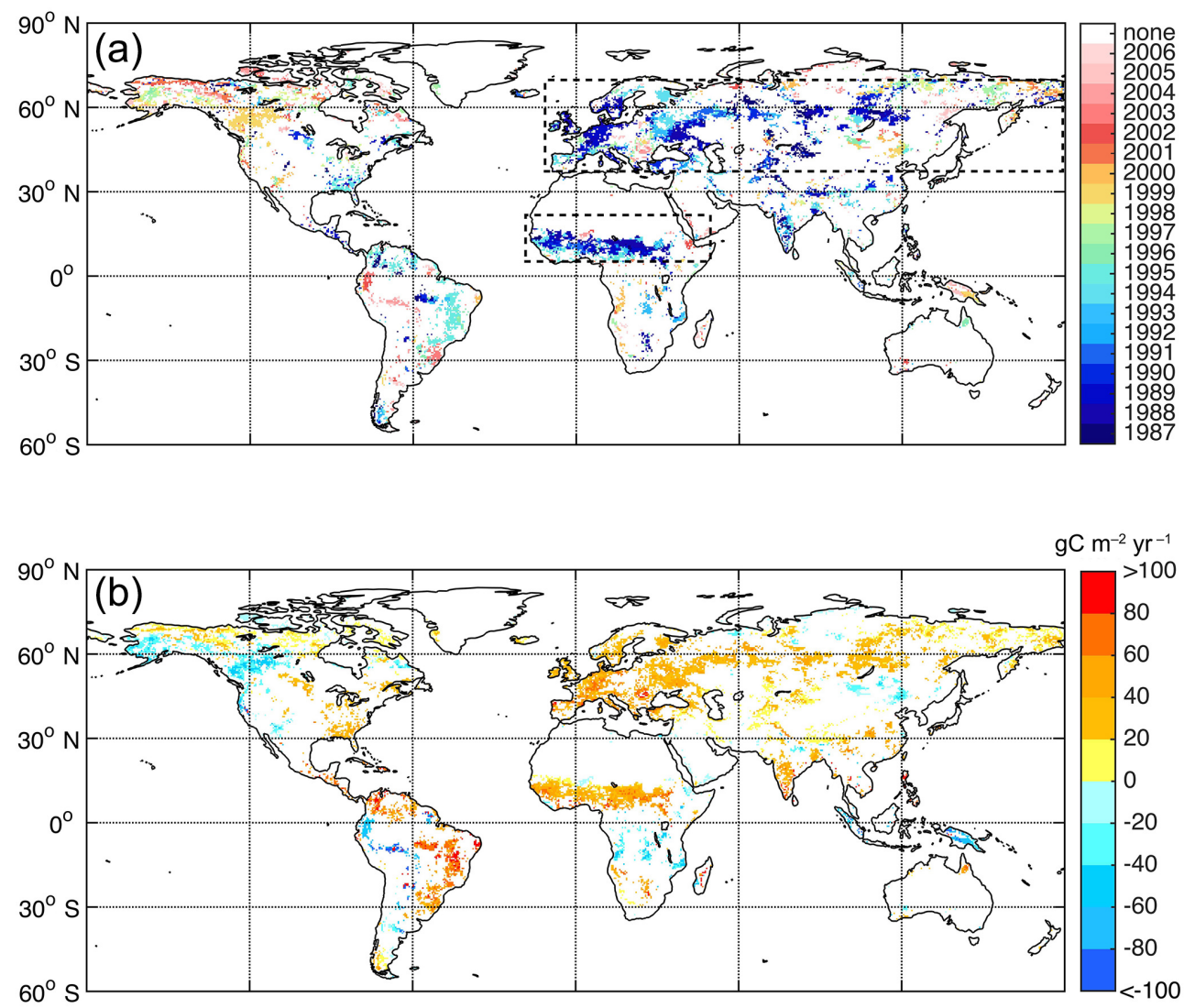

Figure 1. Spatial pattern of abrupt shifts in data-driven NPP. Maps show (a) timing and corresponding (b) direction and magnitude of abrupt shifts in data-driven (CASA) annual NPP for the satellite period 1982-2011. All robust NPP shifts shown here have passed the two key statistical criteria: (i) a "shift-in-the-mean" model fits the time series at each grid point best (evaluated trough the Schwarz information criterion), and (ii) the shift is also statistically significant $(P<0.05)$ based on Monte Carlo simulations that take into account explicit uncertainties (Sect. 2). Maps of shifts that passed only the first criterion are also provided (Fig. S1). In (a), the focus regions northern Eurasia $\left(10^{\circ} \mathrm{W}-180^{\circ} \mathrm{E}, 40-70^{\circ} \mathrm{N}\right)$ and northern Africa $\left(20^{\circ} \mathrm{W}-50^{\circ} \mathrm{E}, 5-20^{\circ} \mathrm{N}\right)$ are outlined. The shifts are only assessed for the period $1987-2006$, since for robust change point detection a minimum span of 5 years of data prior to and after a shift is required (Sect. 2).

decreases in NPP). A similar analysis without constraining to only statistically significant results at the grid point level implies that the coherent pattern of abrupt and sustained NPP shifts across northern Eurasia and northern Africa is spatially even more extensive (Fig. S1 in the Supplement).

This point is further illustrated when we apply our change point framework on data-driven NPP time series representative of large land regions and highlights the important role of the northern extratropics (magnitude of NPP shift: $\left.\sim 0.7 \mathrm{PgC} \mathrm{yr}^{-1}\right)$, and the northern Eurasian continent $\left(\sim 0.5 \mathrm{PgC} \mathrm{yr}^{-1}\right)$ in particular, in the regime shift in carbon uptake by terrestrial plants in the late 1980s (Table 1 and Fig. S2). While the northern African region also exhibits a robust albeit smaller increase in data-driven NPP $\left(\sim 0.2 \mathrm{PgC} \mathrm{yr}^{-1}\right)$ in the late $1980 \mathrm{~s}$, no corresponding NPP shifts are discernable for tropical/southern and global land areas (Table 1). It is well known that factors like the El NiñoSouthern Oscillation (ENSO; van der Werf et al., 2004) and volcanic aerosols (Lucht et al., 2002) have a large influence on variability in the carbon balance of terrestrial ecosystems (particularly at interannual timescales), and these phenomena may have also played a role in the prominent late-1980s NPP regime shifts. An analysis that explicitly accounts for such effects, however, suggests that these two factors are not the causes of the shift but indicates that a shift in data-driven NPP in the late 1980s emerges also for tropical/southern and global land regions, albeit with limited statistical significance (Table 1). In a complementary analysis, we also re-assessed the robustness of the earlier reported abrupt shift in the residual global land carbon sink in the late 1980s (Sarmiento et al., 2010; Beaulieu et al., 2012a) by analyzing a GCB for the period 1959-2011 (Le Quéré et al., 2013) with our change point methodology that also accounts for explicit uncertainties in the individual budget terms (Sect. 2.2). Results confirm the presence of a regime shift in the global residual land sink ( $\sim 1-1.3 \mathrm{PgC} \mathrm{yr}^{-1}$ depending on statistical treatment) in the late 1980s (Table 1 and Fig. S3). Taken together, the good agreement in the timing of regime shifts in the global residual 
Table 1. Timing and magnitude of abrupt changes in the terrestrial carbon cycle at global and continental scales. Timing of abrupt change (first data entry) as well as corresponding direction and magnitude (second data entry in units of $\mathrm{PgC} \mathrm{yr}^{-1}$ ) and $P$ values (in brackets; estimated through Monte Carlo simulations) are provided if a shift-in-the-mean model fits the respective time series best (see Sect. 2). The timing of a shift indicates the first year of a new regime. Shifts that are statistically significant $(P<0.05)$ are highlighted in bold. Additional tests were carried out to assess the nature and robustness of the shifts, including accounting for influences related to ENSO and volcanic eruptions (Covariates), and specifically removing the two years of largest impact of the strong Mt. Pinatubo volcanic eruption in the original time series (no Pinatubo). Plots of all time series analyzed are also provided (Figs. S2-S3).

\begin{tabular}{|c|c|c|c|}
\hline Region & Original data & Covariates ${ }^{\mathrm{f}}$ & No Pinatubog \\
\hline \multicolumn{4}{|c|}{ Global carbon budget 1959-2011 } \\
\hline Residual land sink $\mathrm{k}^{\mathrm{e}}$ & $1989,+1.03(0.003)$ & $1989,+1.28(<0.001)$ & $1989,+1.06(0.003)$ \\
\hline Net land uptake $\mathrm{e}^{\mathrm{e}}$ & $1989,+1.19(0.004)$ & $1989,+1.43(<0.001)$ & $1989,+1.23(0.001)$ \\
\hline \multicolumn{4}{|c|}{ Data-driven (CASA) NPP 1982-2011 } \\
\hline Global & $1995,+1.18(0.239)^{\mathrm{c}}$ & $1989,+1.12(0.124)^{\mathrm{c}}$ & $1989,+1.49(0.084)^{\mathrm{c}}$ \\
\hline Northern land $\left(>30^{\circ} \mathrm{N}\right)$ & $1988,+0.72(0.010)^{\mathrm{c}}$ & $1989,+0.62(0.008)^{\mathrm{c}}$ & $1988,+0.76(0.003)^{\mathrm{c}}$ \\
\hline Tropic./south. land $\left(<30^{\circ} \mathrm{N}\right)$ & $1995,+0.73(0.266)^{\mathrm{c}}$ & $1989,+0.50(0.526)$ & $1995,+0.70(0.388)^{\mathrm{c}}$ \\
\hline Northern Eurasia & $1988,+0.53(<0.001)^{b}$ & $1989,+0.45(0.001)$ & $1988,+0.54(<0.001)^{b}$ \\
\hline Northern Africa & $1989,+0.20(0.005)$ & $1989,+0.17(0.003)$ & $1989,+0.21(0.001)$ \\
\hline \multicolumn{4}{|c|}{ Process-based (CASA) $R_{\mathrm{h}} 1982-2011$} \\
\hline Global & $1996,+0.96(0.001)$ & $1990,+0.80(0.028)^{\mathrm{c}}$ & $1996,+0.94(0.001)$ \\
\hline Northern land $\left(>30^{\circ} \mathrm{N}\right)$ & $1990,+0.44(0.003)^{\mathrm{c}}$ & $1990,+0.42(<0.001)^{\mathrm{a}, \mathrm{c}}$ & $1990,+0.46(<0.001)^{\mathrm{c}}$ \\
\hline Tropic./south. land $\left(<30^{\circ} \mathrm{N}\right)$ & $1996,+0.63(0.003)$ & $1996,+0.49(0.054)$ & $1996,+0.61(0.002)$ \\
\hline Northern Eurasia & $1988,+0.35(0.004)^{\mathrm{a}, \mathrm{c}}$ & $1990,+0.29(0.004)^{\mathrm{b}, \mathrm{c}}$ & $1988,+0.37(<0.001)^{\mathrm{a}, \mathrm{c}}$ \\
\hline Northern Africa & $1988,+0.18(<0.001)$ & $1991,+0.14(0.003)^{b}$ & $1988,+0.19(<0.001)$ \\
\hline \multicolumn{4}{|c|}{ Process-based (CASA) NEP 1982-2011 } \\
\hline Global & $1987^{\mathrm{d}}$ & $1999,-0.68(0.122)$ & $1987^{\mathrm{d}}$ \\
\hline Northern land $\left(>30^{\circ} \mathrm{N}\right)$ & $1987,+0.30(0.318)$ & $1989^{d}$ & $1987,+0.31(0.304)$ \\
\hline Tropic./south. land $\left(<30^{\circ} \mathrm{N}\right)$ & $1999^{d}$ & $1999,-0.56(0.087)$ & $1999^{d}$ \\
\hline Northern Eurasia & $1988,+0.18(0.061)$ & $1989,+0.15(0.154)^{\mathrm{b}, \mathrm{c}}$ & $1988,+0.18(0.074)$ \\
\hline Northern Africa & $1992^{\mathrm{d}}$ & $2003^{\mathrm{d}}$ & $1992^{\mathrm{d}}$ \\
\hline \multicolumn{4}{|c|}{ a Not normally distributed (Lilliefors test, $5 \%$ critical level) } \\
\hline \multicolumn{4}{|c|}{$\begin{array}{l}{ }^{\mathrm{b}} \text { Variance not constant ( } F \text {-test, } 5 \% \text { critical level) } \\
{ }^{c} \text { Residuals not independent (Kruskal-Wallis, } 5 \% \text { critical level) }\end{array}$} \\
\hline \multicolumn{4}{|c|}{$\begin{array}{l}\text { d "Linear trend" or "constant mean" model fits data better than a shift-in-the-mean model } \\
\text { e In the global carbon budget (Le Quéré et al., 2013), the net land uptake is estimated as the difference between global fossil fuel emissions and the } \\
\text { sum of atmospheric } \mathrm{CO}_{2} \text { growth rate and oceanic uptake, while the residual land sink is the difference between net land uptake and LUC emissions }\end{array}$} \\
\hline \multicolumn{4}{|c|}{$\begin{array}{l}\text { f Variability related to ENSO and volcanoes was removed in the original time series through regressions against the multivariate ENSO index and } \\
\text { stratospheric optical thickness after Beaulieu et al. (2012a) } \\
\mathrm{g} \text { The two Pinatubo years }(1992,1993) \text { were removed in the original time series prior to change point analysis }\end{array}$} \\
\hline
\end{tabular}

land carbon sink and continental data-driven NPP may imply that the latter is a significant driver of the increased terrestrial carbon uptake in the late 1980s.

\subsection{Drivers of the late-1980s shift in data-driven NPP}

In order to unravel the mechanisms leading to the continental shifts in data-driven NPP, we focus on the two target regions of northern Eurasia and northern Africa that predominantly contributed to this late-1980s shift (see Fig. 1a). A factorial analysis for specific seasons shows that the northern Eurasian continent experienced a marked increase in spring temperatures and spring satellite vegetation activity (fAPAR) in the late 1980s that together produced a substantial increase in spring NPP (Fig. 2a). This relatively sudden springtime warming was also associated with a markedly earlier spring onset ( $\sim 5$ days; see Fig. S4), and the enhanced productivity in the early part of the growing season appears to have also benefited plant productivity in subsequent summers (Figs. 2a and S4). A closer inspection shows that the increase in summer productivity stemmed solely from satellite fAPAR contributions (Fig. 2a), which is consistent with the notion of a more developed canopy during the peak of the growing season (as captured trough fAPAR) that carries over the early spring onset signal (Richardson et al., 2010). Increased plant productivity in the spring and summer seasons contributed 

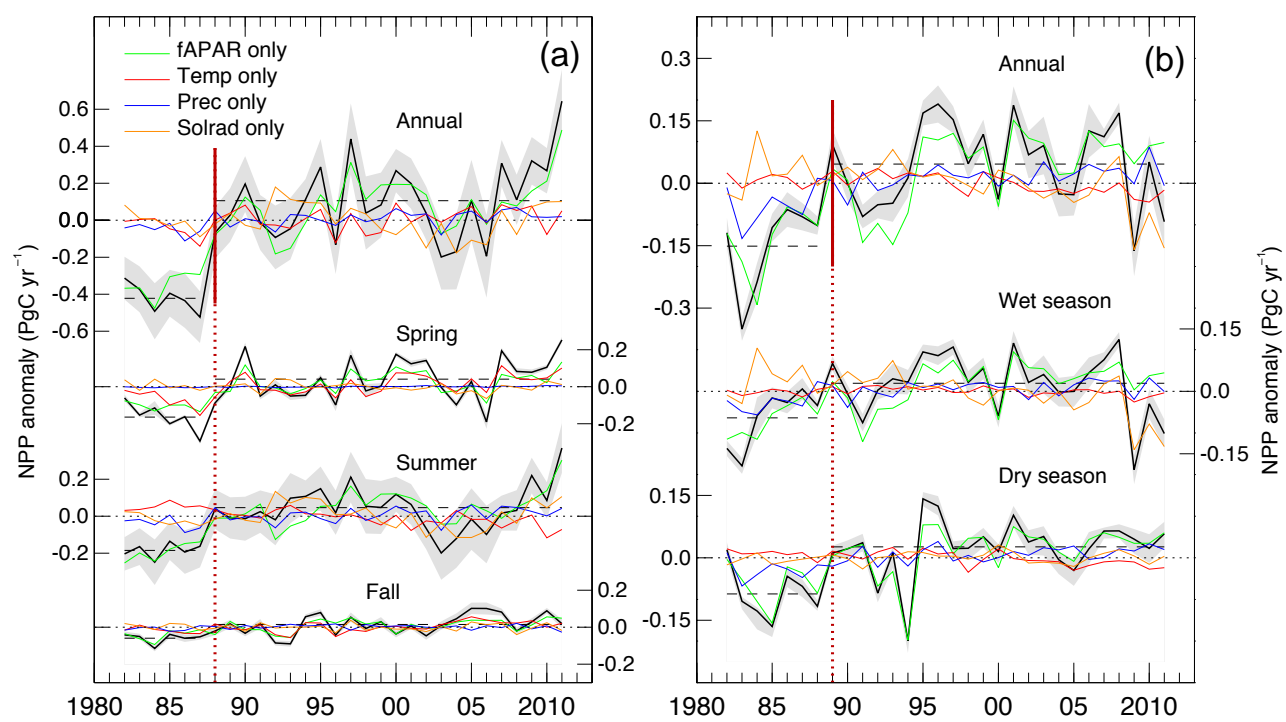

Figure 2. Temporal changes in continental data-driven NPP. Panels show annual and seasonal (CASA-based) NPP anomalies corresponding to the (a) northern Eurasian and (b) northern African focus regions (see Fig. 1a). All anomalies are relative to 1982-2011. Shaded contours represent $1 \sigma$ uncertainties that account for biases in model driver data (Sect. 2). To understand which factors are mainly responsible for the identified shifts (see Table 1), we performed factorial NPP simulations in which only one model driver is varied whereas all others are kept constant (e.g., "fAPAR only" corresponds to NPP simulations in which only fAPAR was varied whereas temperature, precipitation and solar radiation data were kept at their climatological mean values). It should be noted that satellite fAPAR, a proxy for vegetation cover, is often correlated with climate variables; this places limits on attributing a single model driver to changes in NPP. The first year of a new regime in annual NPP is outlined (thick dark-red vertical lines; see Table 1), and the means in NPP anomalies prior to and after the shift are also shown (dashed lines).

predominantly to the pronounced and sustained increases in annual NPP in the late 1980s (Fig. 2a).

Over northern Africa including the dry Sahel, marked increases in data-driven NPP during wet and dry seasons that are driven both by increases in rainfall and by satellite fAPAR triggered a pronounced increase in annual NPP in the late 1980s (Fig. 2b). A closer inspection shows that in the period after this shift rainfall increased specifically during the later portion of the rainy season, which effectively lengthened the more productive growing season (Fig. S4).

\subsection{Shifts in process-based NPP}

The exploited biogeochemical model (CASA) for datadriven NPP simulations has a relatively simple structure and provides an integrated view (via satellite fAPAR) of the many interacting factors that influence NPP variability. Further, data-driven NPP estimates are also influenced by observational uncertainties in both satellite (e.g., volcanic aerosols, cloud cover, signal saturation) and key climate driver data that are only partially accounted for in our data-driven NPP simulations (see Sect. 2.1). We thus explored if processbased terrestrial biosphere models driven by climate and atmospheric $\mathrm{CO}_{2}$ observations also show evidence of a marked shift in NPP in the late 1980s. Results based on the TRENDY ensembles (Sect. 2$)$ show that for the satellite period ( $\sim$ last 3 decades) a NPP shift in the late 1980s emerges as a promi- nent feature, but only in experiments that capture variability due to climate exclusively (Figs. 3, S5 and Table S1). Regional attributions associated with the shift are similar to those in the case for data-driven NPP, but differences in NPP sensitivities to climate (inferred from differences in the magnitude of the shifts) are evident (Tables 1 and S1). For example, the magnitude of the late-1980s NPP shift in northern Eurasia based on TRENDY is only about half the size of the corresponding shift in data-driven NPP (Tables 1 and S1). One reason for this marked difference may be that seasonal carry-over effects in NPP are largely absent in the TRENDY models; e.g., the late-1980s northern Eurasian annual NPP shift in TRENDY is solely due to spring contributions (coincident with the time of the climate forcing), whereas for data-driven NPP it is comprised of about equal contributions from spring and summer, with satellite fAPAR providing the link through which the early spring onset signal is propagated (Figs. 2a and 3a). It should be noted that such seasonal carry-over effects due to an earlier spring onset are observed at multiple eddy covariance flux sites across temperate and boreal ecosystems (Richardson et al., 2010) and that the phenology response (at seasonal and interannual timescales) in data-driven approaches is generally considered more robust (Raczka et al., 2013).

The TRENDY simulations are not restricted to the satellite period, allowing us to assess whether the identified late- 

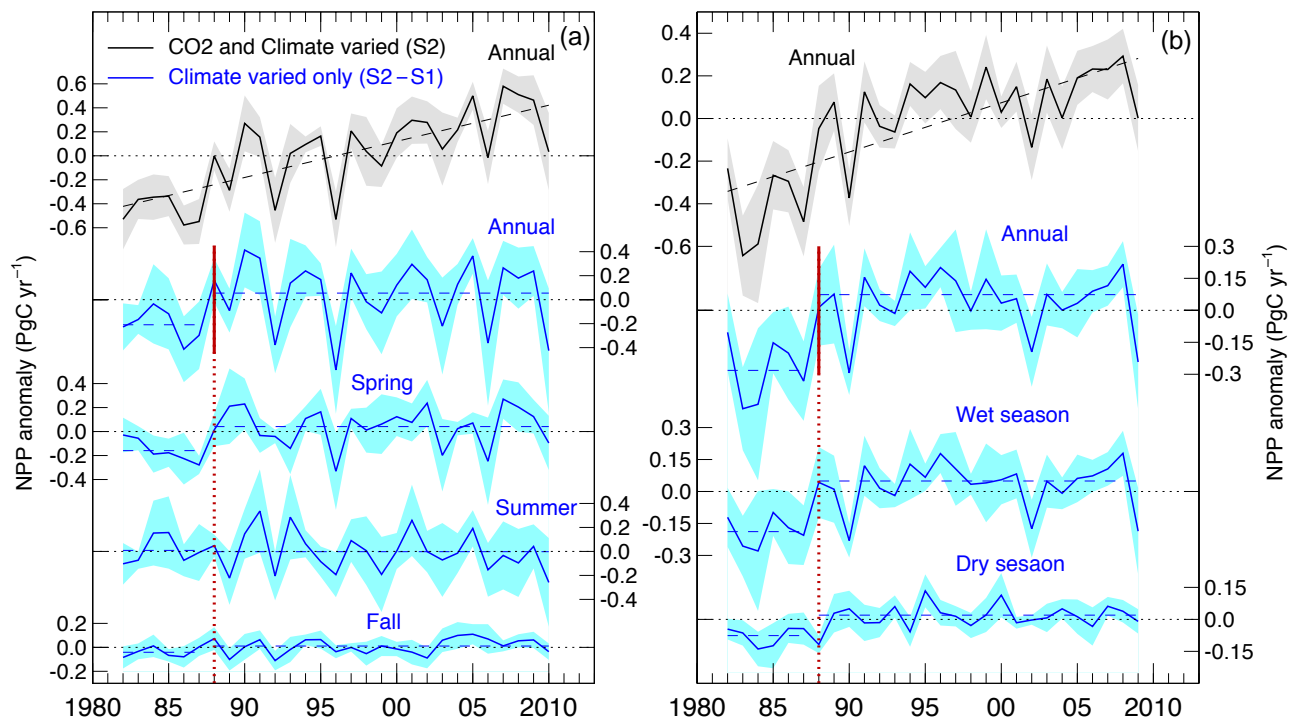

Figure 3. Temporal changes in continental process-based NPP based on nine terrestrial biosphere models. Panels show annual and seasonal NPP anomalies for the (a) northern Eurasian and (b) North African focus regions, based on ensembles of nine biosphere models that participated in the recent TRENDY model intercomparison study (Sitch et al., 2015). In the annual case, results for two sets of model simulations are shown: one in which climate and $\mathrm{CO}_{2}$ as model drivers were varied (S2) and another one that only takes into account the effect of climate variations (S2-S1; see Sect. 2). All anomalies are relative to the 1982-2010 overlapping satellite era to facilitate comparisons with the data-driven NPP simulations (see Fig. 2). Mean ensembles were formed based on anomalies in the single TRENDY models to emphasize temporal changes in NPP and to suppress uncertainties arising from model differences in magnitudes. Shaded contours represent $1 \sigma$ uncertainties corresponding to the spread in the single TRENDY models. The first year of a new regime in annual NPP is outlined (thick dark-red vertical lines; Table S1), and the means in NPP anomalies prior to and after the shift are also shown (dashed lines). In panel (b), the last data point for the year 2010 is omitted since tropical rainfall input data for the TRENDY runs were erroneous for that year (S. Sitch, personal communication, 2015).

1980s NPP shifts also emerge as the dominant pattern when the study period is extended to the last 5 decades (to be consistent with the time frame of the GCB). Results show that the late-1980s shift over northern Eurasia is a stable pattern. For northern Africa, however, an even more prominent shift is identified in the late 1960s (Fig. S5 and Table S1). This may suggest that this region by itself is not important enough to influence the global land sink (since there is no evidence for a corresponding shift in the global residual land sink; see Table 1). Further, in TRENDY experiments in which atmospheric $\mathrm{CO}_{2}$ and climate drivers are varied, the shift appears to be masked by an increasing trend in NPP associated largely with the $\mathrm{CO}_{2}$ fertilization effect (Figs. 3, S6 and Table S1). In fact, the high NPP sensitivity to changes in atmospheric $\mathrm{CO}_{2}$ concentrations in many of the current generation of terrestrial biosphere models (Arora et al., 2013) and the potential role of nutrient limitations (Zaehle, 2013) and/or climate feedbacks (Smith et al., 2016) in mitigating this sensitivity are presently a subject of intense research.

\subsection{Shifts in $R_{\mathrm{h}}$ and NEP}

The extent to which the identified climate-driven regime shifts in NPP in the late 1980s translate into a sustained carbon sink (consistent with the shift seen in the residual land carbon sink from the GCB; Table 1) depends in part on associated responses in key carbon loss fluxes such as $R_{\mathrm{h}}$, which (apart from its dependence on substrate supply from NPP) often depends on climatic factors in a similar fashion to NPP (Lucht et al., 2002). A limitation, however, is that currently no data-driven analog for $R_{\mathrm{h}}$ estimation exists, and one has to revert to alternative methods including more uncertain process-based simulations. Nevertheless to estimate the degree at which shifts in NPP may be potentially offset by corresponding shifts in $R_{\mathrm{h}}$, we apply our change point framework also on the $R_{\mathrm{h}}$ as well as NEP fluxes from the CASA and TRENDY simulations (see Sect. 2). Results show that, for the large land regions of interest, regime shifts in NPP are repeatedly accompanied by substantial shifts in $R_{\mathrm{h}}$ (Tables 1, S1-S2; Figs. S2, S5-S6) often with 1-2-year lags (seen most clearly when ENSO and volcanic influences are accounted for). A consequence is that corresponding shifts in NEP are often less robust or not detectable (Tables 1 and S3). For example, in the case of the two focal regions northern Eurasia and northern Africa, the late-1980s shifts in datadriven NPP are offset by corresponding shifts in $R_{\mathrm{h}}$ at levels of 64-66 and 80-90\% (depending on statistical treatment), respectively (Table 1). As stated, the estimated shifts in the $R_{\mathrm{h}}$ fluxes are more uncertain and may represent more upper- 
bound estimates as a new study suggests that carbon models have a tendency to transfer carbon too quickly through the plant-soil systems because of severe biases in simulated soil carbon and/or too-high $R_{\mathrm{h}}$ sensitivities to climate (Carvalhais et al., 2014).

At global scale, a shift in $R_{\mathrm{h}}$ can also be estimated as the residual between a NPP shift and a corresponding shift in the residual land sink based on the GCB (Anderegg et al., 2015). Using methods that include such residual calculations as well as our direct model estimates (see Methods in the Supplement), we estimate a shift in global NPP in the late 1980s of $1.14 \pm 0.34 \mathrm{PgC} \mathrm{yr}^{-1}$ and a corresponding shift in $R_{\mathrm{h}}$ of $0.36 \pm 0.48 \mathrm{PgC} \mathrm{yr}^{-1}$. Our best estimate for an associated global shift in NEP is $0.63 \pm 0.30 \mathrm{PgC} \mathrm{yr}^{-1}$, which amounts to roughly $60 \%$ of the magnitude of the late-1980s shift in the residual land sink from the GCB $\left(1.12 \pm 0.14 \mathrm{PgC} \mathrm{yr}^{-1}\right.$; based on the three estimates shown in Table 1).

\section{Discussion}

Our findings provide independent evidence from a biospheric modeling perspective for the abrupt strengthening of the residual land carbon sink in the late 1980s (Sarmiento et al., 2010) and suggest that the underlying driver is a shift in global NPP in response to coordinated large-scale climate shifts. However, the late-1980s climate perturbations may also substantially influence fire regimes, but the paucity of data on burned area and related carbon emissions extending back to the early 1980s severely limits estimating corresponding impacts. For northern Eurasia (which is responsible for the largest contribution to the late-1980s regime shift in data-driven NPP), however, it is not expected that the observed profound spring warming and greening (inferred through fAPAR) in the late 1980s may have led to substantial changes in fire emissions since the fire activity peaks later in the season (van der Werf et al., 2006). For northern Africa, changes in fire regimes associated with the late-1980s shift towards wetter conditions may have a substantial influence on net carbon balance, albeit with uncertain direction since a shift towards wetter conditions may increase (more fuel load) or reduce (shortening the dry season) fire emissions (Andela and van der Werf, 2014). Models that can potentially quantify this influence are still in their early phase of development. While much uncertainty (specifically pertaining to magnitude) remains in estimating the contribution of climate-driven changes in the major land carbon fluxes to the late-1980s regime shift in the land carbon sink, our regional NPP attributions are consistent with a reported decrease in the interhemispheric gradient in atmospheric $\mathrm{CO}_{2}$ in the 1990s relative to the 1980s that is attributed to an increase in the northern carbon sink (Wang et al., 2013).

Other factors not related to climate may have also played a role in the late-1980s regime shift of the land carbon sink. A potentially large contribution in this regard may be

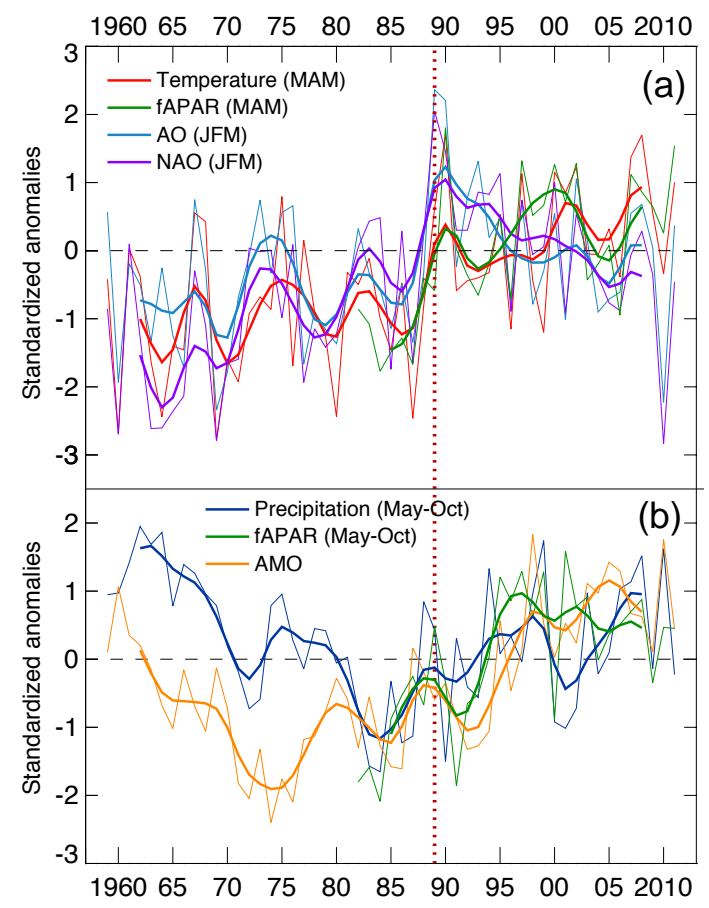

Figure 4. Synchronous continental shifts in climate and satellite vegetation data and links to North Atlantic climate variability. In panel (a), temporal variations in spring (MAM) temperature and satellite-based vegetation activity (fAPAR) representative of the northern Eurasian target region are plotted alongside the winter (JFM) Arctic Oscillation (AO) and North Atlantic Oscillation (NAO) time series. In panel (b), temporal variations in wet-season (May-Oct) precipitation and fAPAR for the northern African target region are plotted alongside the annual Atlantic Multidecadal Oscillation (AMO) time series. Plotted are both annual values (thin dotted lines) and a smoothed time series based on a seven-point binomial filter (thick lines). All time series are standardized anomalies relative to the satellite period 1982-2011. All climate indices' time series are obtained from www.esrl.noaa.gov. Definitions of the AO and NAO are given in Thompson and Wallace (1998) and Hurrell (1995), respectively. The AMO is a detrended area-weighted average of North Altantic SSTs $\left(0-70^{\circ} \mathrm{N}\right)$ (Enfield et al., 2001).

from land-use and land-cover changes across northern Eurasia through agricultural abandonment and rapid changes in forest management in the aftermath of the late-1980s Soviet collapse. While such processes are accounted for in net LUC emission estimates compiled in the GCB (and therefore included in our analysis; see Table 1), corresponding effects may not be fully captured due to a lack of robust data especially in the period prior to the Soviet collapse (Achard et al., 2006). However, at least in the case of agricultural abandonment newly available estimates (Schierhorn et al., 2013) of associated carbon sinks for the post-Soviet period 19902009 suggest a minor contribution $\left(\sim 0.03 \mathrm{PgC} \mathrm{yr}^{-1}\right)$.

A remarkable finding is that two key climatic constraints on plant growth (temperature and precipitation) shifted in the late 1980s in such a way as to facilitate an abrupt and 
sustained increase in continental-scale terrestrial NPP. This bears the question of whether there is an underlying link that would explain why these large-scale climate patterns varied nearly synchronously. The Arctic Oscillation (AO) is the most important climate mode in the northern extratropics (Thompson and Wallace, 1998) and also a prominent mode in coupled global (Los et al., 2001) and hemispheric (Buermann et al., 2003) climate and satellite vegetation greenness data. Consistent with these results, we find that over the satellite period 1982-2011 the winter AO is tightly correlated with northern Eurasian spring temperatures $(r=0.60, P<0.001)$ and spring fAPAR ( $r=0.40, P=0.03$ ) (Fig. 4). In the late 1980 s, the AO together with its regional manifestation the North Atlantic Oscillation (NAO) (Hurrell, 1995) underwent an extreme shift into their respective positive phases, thereby moving North Atlantic winter storm tracks northward and enabling advection of mild maritime air deep into the northern Eurasian land mass (Thompson and Wallace, 1998). Our results show that the northern Eurasian biomes responded rapidly to the associated substantial spring warming as evidenced through synchronous increases in satellite-based vegetation activity (Fig. 4a). Change point analysis on these drivers of NPP also confirms the existence of this prominent late-1980s shift (showing significant shifts in winter (JFM) AO $(1989, p=0.07)$, northern Eurasian spring temperature $(1989, p<0.001)$ and northern Eurasian spring fAPAR (1990, $p<0.001)$ ). In the aftermath of this shift, however, spring temperatures and vegetation activity stayed at elevated levels (causing a sustained impact on plant carbon uptake; see Fig. 2a), while the AO/NAO exhibited a negative trend, a fact that may be explained by a more gradual warming response to greenhouse gas forcing that is superimposed on the more oscillatory influence of the AO/NAO.

Northern African wet-season rainfall patterns are strongly influenced by Atlantic sea surface temperature (SST) variability (Hoerling et al., 2006). In this regard, the warming of the North Atlantic relative to the South Atlantic that resumed in the late 1980s to mid-1990s caused a northward displacement of the Atlantic intertropical convergence zone (ITCZ) and increased rainfall rates across northern Africa, which led to a recovery from earlier severe drought conditions (Hoerling et al., 2006). This increased moisture supply also led to rapid increases in satellite fAPAR (Fig. 4b). An open question is to what extent $\mathrm{AO} / \mathrm{NAO}$ and Atlantic SST forcings may have interacted (Xie and Carton, 2004) in the wake of the apparent coordinated regional climate shifts over northern Eurasia and northern Africa in the late 1980s. It is well established that ENSO (van der Werf et al., 2004) and volcanic eruptions (Lucht et al., 2002) have a dominant influence on the terrestrial carbon cycle at interannual timescales, and much of recent research has focused on associated links (Cox et al., 2013; Wang et al., 2014). Our findings here may suggest that North Atlantic climate variability and corresponding impacts on adjacent vast land masses may be more important in regards to abrupt, substantial and more sustained shifts in the terrestrial carbon cycle.

\section{Conclusions}

Our results point to a mechanism whereby North Atlantic climate variability modulates the global terrestrial carbon cycle. New research suggests that a large portion of the variability in the North Atlantic may be externally forced by anthropogenic aerosols (Booth et al., 2012) and the pronounced warming trend in the Arctic regions, known as Arctic amplification (Cohen et al., 2014). Arctic amplification specifically is thought to intensify under climate change (Deser et al., 2010), and this may drive the AO/NAO more into their respective negative phases (Cohen et al., 2014), which, based on our results, would substantially reduce carbon uptake by terrestrial plants and weaken the land carbon sink. This illustrates the pressing need for improved knowledge of North Atlantic climate variability and associated forcing mechanisms in order to more credibly project the evolution of the land carbon sink and carbon cycle climate feedbacks under climate change.

\section{The Supplement related to this article is available online at doi:10.5194/bg-13-1597-2016-supplement.}

Author contributions. W. Buermann, C. Beaulieu, B. Parida and G. J. Collatz designed the analyses. W. Buermann, C. Beaulieu and B. Parida conducted the analyses. All authors contributed to the writing of the manuscript.

Acknowledgements. We gratefully acknowledge support for this study from the National Aeronautics and Space Administration Carbon Cycle Science Program (grant NNX11AD45G).

We also thank Emanuel Gloor, Stephen Sitch, John Chiang and Chris Jones as well as two anonymous reviewers for constructive comments that improved the manuscript substantially. Finally, we thank the TRENDY modeling group for making their data available.

Edited by: S. Zaehle

\section{References}

Achard, F., Mollicone, D., Stibig, H. J., Aksenov, D., Laestadius, L., Li, Z., Popatov, P., and Yaroshenko, A.: Areas of rapid forest cover change in boreal Eurasia, For. Ecol. Manag., 237, 322-334, 2006.

Andela, N. and van der Werf, G. R.: Recent trends in African fires driven by cropland expansion and El Nino to La Nina transition, Nature CC, 4, 791-795, 2014. 
Anderegg, W. R. L., Ballantyne, A. P., Smith, W. K., Majkut, J., Rabin, S., Beaulieu, C., Birdsey, R., Dunne, J. P., Houghton, R. A., Myneni, R. B., Pan, Y., Sarmiento, J. L., Serota, N., Shevliakova, E., Tans, P., and Pacala, S. W.: Tropical nighttime warming as a dominant driver of variability in the terrestrial carbon sink, P. Natl. Acad. Sci. USA, 112, 15591-15596, doi:10.1073/pnas.1521479112, 2015.

Arora, V. K., Boer, G. J., Friedlingstein, P., Eby, M., Jones, C. D., Christian, J. R., Bonan, G., Bopp, L., Brovkin, V., Cadule, P., Hajima, T., Ilyina, T., Lindsay, K., Tjiputra, J. F., and Wu, T.: Carbon-concentration and carbon-climate feedbacks in CMIP5 earth system models, J. Climate, 26, 5289-5314, 2013.

Beaulieu, C., Sarmiento, J. L., Mikaloff Fletcher, S., Chen, J., and Medvigy, D.: Identification and characterization of abrupt changes in the land uptake of carbon, Glob. Biogeochem. Cy., 26, GB1007, doi:10.1029/2010GB004024, 2012a.

Beaulieu, C., Chen, J., and Sarmiento, J. L.: Change-point analysis as a tool to detect abrupt climate variations, in special issue: Climate predictions: the influence of nonlinearity and randomness, Philos. T. R. Soc. A, 370, 1228-1249, 2012b.

Booth, B. B. B., Dunstone, N. J., Halloran, P. R., Andrews, T., and Bellouin, N, Aerosols implicated as a prime driver of twentiethcentury North Atlantic climate variability, Nature, 484, 228-232, 2012.

Buermann, W., Anderson, B., Tucker, C. J., Dickinson, R. E., Lucht, W., Potter, C. S., and Myneni, R. B.: Interannual covariability in Northern Hemisphere air temperatures and greenness associated with El Niño-Southern Oscillation and the Arctic Oscillation, J. Geophys. Res., 108, 4396, doi:10.1029/2002JD002630, 2003.

Carvalhais, N., Forkel, M., Khomik, M., Bellarby, J., Jung, M., Migliavacca, M., Mu, M., Saatchi, S., Santoro, M., Thurner, M., Weber, U., Ahrens, B., Beer, C., Cescatti, A., Randerson, J. T., and Reichstein, M.: Global covariation of carbon turnover times with climate in terrestrial ecosystems, Nature, 514, 213-217, 2014.

Ciais, P., Sabine, C., Bala, G., Bopp, L., Brovkin, V., Canadell, J., Chhabra, A., DeFries, R., Galloway, J., Heimann, M., Jones, C., Le Quéré, C., Myneni, R. B., Piao, S., and Thornton, P: in: IPCC Climate Change 2013: The Physical Science Basis, edited by: Stocker, T. F., Qin, D., Plattner, G.-K., Tignor, M., Allen, S. K., Boschung, J., Nauels, A., Xia, Y., Bex, V., and Midgley, P. M., Cambridge University Press, Cambridge, 465-570, 2013.

Cohen, J., Screen, J. A., Furtado, J. C., Barlow, M., Whittleston, D., Coumou, D., Francis, J., Dethloff, K., Entekhabi, D., Overland J., and Jones, J.: Recent Arctic amplification and extreme midlatitude weather, Nat. Geosci., 7, 627-637, 2014.

Cox, P. M., Pearson, D., Booth, B. B., Friedlingstein, P., Huntingford, C., Jones, C. D., and Luke, C. M.: Sensitivity of tropical carbon to climate change constrained by carbon dioxide variability, Nature, 494, 341-344, 2013.

Denman, K. L., Brasseur, G., Chidthaisong, A., Ciais, P., Cox, P. M., Dickinson, R. E., Hauglustaine, D., Heinze, C., Holland, E., Jacob, D., Lohmann, U., Ramachandran, S., da Silva Dias, P. L., Wofsy, S. C., and Zhang, X.: in: IPCC Climate Change 2007: The Physical Science Basis, edited by: Solomon, S., Qin, D., Manning, M., Chen, Z., Marquis, M., Averyt, K. B., Tignor, M., and Miller, H. L., Cambridge University Press, Cambridge, 499-587, 2007.
Deser, C., Tomas, R., Alexander, M. , and Lawrence, D.: The seasonal atmospheric response to projected Arctic sea ice loss in the late twenty-first century, J. Climate, 23, 333-351, 2010.

Donohue, R. J., Roderick, M. L., McVicar, T. R., and Farquhar, G. D.: $\mathrm{CO}_{2}$ fertilisation has increased maximum foliage cover across the globe's warm, arid environments, Geophys. Res. Lett., 40, 3031-3035, 2013.

Enfield, D. B., Mestas-Nunez, A. M., and Trimble, P. J.: The Atlantic Multidecadal Oscillation and its relationship to rainfall and river flows in the continental U.S., Geophys. Res. Lett., 28, 2077-2080, 2001

Forkel, M., Migliavacca, M., Thonicke, K., Reichstein, M., Schaphoff, S., Weber, U. and Carvalhais, N.: Codominant water control on global interannual variability and trends in land surface phenology and greenness, Glob. Change Biol., 21, 34143435, 2015.

Greve, P., Orlowsky, B., Mueller, B., Sheffield, J., Reichstein, M., and Seneviratne, S. I.: Global assessment of trends in wetting and drying over land, Nat. Geosci., 7, 716-721, doi:10.1038/ngeo2247, 2014.

Harris, I., Jones, P. D., Osborna, T. J., and Lister, D. H.: Updated high-resolution grids of monthly climate observations - the CRU TS3.10 dataset, Int. J. Climatol., 34, 623-642, 2014.

Hoerling, M. J., Hurrell, J., Eischeid, J., and Phillips, A.: Detection and attribution of 20th century Northern and Southern African rainfall change, J. Climate, 19, 3989-4008, 2006.

Hurrell, J. W.: Decadal trends in the North Atlantic oscillation regional temperatures and precipitation, Science, 269, 676-679, 1995.

IPCC: Climate Change 2013: The Physical Science Basis: Summary for Policymakers, edited by: Stocker, T. F. Qin, D., Plattner, G.-K., Tignor, M., Allen, S. K., Boschung, J., Nauels, A., Xia, Y., Bex, V., and Midgley, P. M., Cambridge University Press, Cambridge, 2013.

Kurz, W. A., Dymond, C. C., Stinson, G., Rampley, G. J., Neilson, E. T., Carroll, A. L., Ebata, T., and Safranyik, L.: Mountain pine beetle and forest carbon feedback to climate change, Nature, 452, 987-990, 2008.

Le Quéré , C., Raupach M. R., Canadell, J. G., Marland, G., Bopp, L., Ciais, P., Conway, T. J., Doney, S. C., Feely, R. A., Foster P, Friedlingstein, P., Gurney, K., Houghton, R. A., House, J. I., Huntingford, C., Levy, P. E., Lomas, M. R., Majkut, J., Metzl, N., Ometto, J. P., Peters, G. P., Prentice, I. C., Randerson, J. T., Running, S. W., Sarmiento, J. L., Schuster, U., Sitch, S., Takahashi, T., Viovy, N., van der Werf, G. R., and Woodward, F. I.: Trends in the sources and sinks of carbon dioxide, Nat. Geosci., 2, 831-836, 2009.

Le Quéré, C., Andres, R. J., Boden, T., Conway, T., Houghton, R. A., House, J. I., Marland, G., Peters, G. P., van der Werf, G. R., Ahlström, A., Andrew, R. M., Bopp, L., Canadell, J. G., Ciais, P., Doney, S. C., Enright, C., Friedlingstein, P., Huntingford, C., Jain, A. K., Jourdain, C., Kato, E., Keeling, R. F., Klein Goldewijk, K., Levis, S., Levy, P., Lomas, M., Poulter, B., Raupach, M. R., Schwinger, J., Sitch, S., Stocker, B. D., Viovy, N., Zaehle, S., and Zeng, N.: The global carbon budget 1959-2011, Earth Syst. Sci. Data, 5, 165-185, doi:10.5194/essd-5-165-2013, 2013.

Los, S. O., Collatz, G. J., Bounoua, L., Sellers, P. J., and Tucker, C. J.: Global interannual variations in sea surface temperature 
and land surface vegetation, air temperature, and precipitation, $\mathrm{J}$. Climate, 14, 1535-1550, 2001.

Los, S.: Analysis of trends in fused AVHRR and MODIS NDVI data for 1982-2006: Indication for a $\mathrm{CO}_{2}$ fertilization effect in global vegetation, Glob. Biogeochem. Cy., 27, 318-330, 2013.

Lucht, W., Prentice, I. C., Myneni, R. B., Sitch, S., Friedlingstein, P., Cramer, W., Bousquet, P., Buermann, W., and Smith, B.: Climatic control of the high-latitude vegetation greening trend and Pinatubo effect, Science, 296, 1687-1688, 2002.

Luyssaert, S., Inglima, I., Jung, M., Reichstein, M., Papale, D., Piao, S., Schulze, E.-D., Wingate, L., Matteucci, G., Aubinet, M., Beer, C., Bernhofer, C., Black, K. G., Bonal, D., Chambers, J., Ciais, P., Davis, K. J., Delucia, E. H., Dolman, A., Don, A., Gielen, B., Grace, J., Granier, A., Grelle, A., Griffis, T., Grnwald, T., Guidolotti, G., Hanson, P., Harding, R., Hollinger, D., Kolari, P., Kruijt, B., Kutsch, W., Lagergren, F., Laurila, T., Law, B., Le Maire, G., Lindroth, A., Magnani, F., Marek, M., Mateus, J., Migliavacca, M., Misson, L., Montagnani, L., Moncrieff, J., Moors, E., Munger, J. W., Nikinmaa, E., Loustau, D., Pita, G., Rebmann, C., Richardson, A. D., Roupsard, O., Saigusa, N., Sanz, M., Seufert, G., Soerensen, L., Tang, J., Valentini, R., Vesala, T., and Janssens, I. A.: $\mathrm{CO}_{2}$ balance of boreal, temperate, and tropical forests derived from a global database, Glob. Change Biol., 13, 2509-2537, 2007.

Piao, S., Wang, X., Ciais, P., Zhu, B., Wang, T., and Liu, J.: Changes in satellite-derived vegetation growth trend in temperate and boreal Eurasia from 1982 to 2006, Glob. Change Biol., 17, 3228 3239, 2011.

Piao, S., Sitch, S., Ciais, P., Friedlingstein, P., Peylin, P., Wang, X. H., Ahlström, A., Anav, A., Canadell, J. G., Huntingford, C., Jung, M., Levis, S., Levy, P. E., Li, J. S., Lin, X., Lomas, M. R., Lu,M., Luo, Y. Q., Ma, Y. C., Myneni, R. B., Poulter, B., Sun, Z. Z., Wang, T., Viovy, N., Zaehle, S., and Zeng, N.: Evaluation of terrestrial carbon cycle models for their response to climate variability and to $\mathrm{CO}_{2}$ trends, Glob. Change Biol., 19, 2117-2132, 2013.

Raczka, B. M., Davis, K. J., Huntzinger, D. N., Neilson, R., Poulter, B., Richardson, A., Xiao, J. F., Baker, I., Ciais, P., Keenan, T. F., Law, B., Post, W. M., Ricciuto, D., Schaefer, K., Tian, H. Q., Tomelleri, E., Verbeeck, H., and Viovy, N.: Evaluation of continental carbon cycle simulations with North American flux tower observations, Ecol. Monographs, 83, 531-556, 2013.

Richardson, A. D.: Influence of spring and autumn phenological transitions on forest ecosystem productivity, Phil. Trans. R. Soc. B, 365, 3227-3246, 2010.

Sarmiento, J. L., Gloor, M., Gruber, N., Beaulieu, C., Jacobson, A. R., Mikaloff Fletcher, S. E., Pacala, S., and Rodgers, K.: Trends and regional distributions of land and ocean carbon sinks, Biogeosciences, 7, 2351-2367, doi:10.5194/bg-7-2351-2010, 2010.

Schierhorn, F., Müller, D., Beringer, T., Prishchepov, A. V., Kuemmerle, T., and Balmann, A.: Post-Soviet cropland abandonment and carbon sequestration in European Russia, Ukraine, and Belarus, Glob. Biogeochem. Cy., 27, 1175-1185, 2013.

Sitch, S., Friedlingstein, P., Gruber, N., Jones, S. D., MurrayTortarolo, G., Ahlström, A., Doney, S. C., Graven, H., Heinze, C., Huntingford, C., Levis, S., Levy, P. E., Lomas, M., Poulter, B., Viovy, N., Zaehle, S., Zeng, N., Arneth, A., Bonan, G., Bopp, L., Canadell, J. G., Chevallier, F., Ciais, P., Ellis, R., Gloor, M., Peylin, P., Piao, S. L., Le Quéré, C., Smith, B.,
Zhu, Z., and Myneni, R.: Recent trends and drivers of regional sources and sinks of carbon dioxide, Biogeosciences, 12, 653679, doi:10.5194/bg-12-653-2015, 2015.

Smith, W. K., Reed, S. C., Cleveland, C. C., Ballantyne, A. P., Anderegg, W. R. L., Wieder, W. R., Liu, Y. Y., and Running, S. W.: Large divergence of satellite and Earth system model estimates of global terrestrial $\mathrm{CO}_{2}$ fertilization, Nature Clim. Change, 6 , 306-310, doi:10.1038/nclimate2879, 2016.

Thompson, D. W. J. and Wallace, J. M.: The Arctic oscillation signature in the wintertime geopotential height and temperature fields, Geophys. Res. Lett., 25, 1297-1300, 1998.

van der Werf, G. R., Randerson, J. T., Collatz, G. J., Giglio, L., Kasibhatla, P. S., Arellano Jr., A. F., Olsen, S. C., and Kasischke, E. S.: Continental-scale partitioning of fire emissions during the 1997 to 2001 El Nino/La Nina period, Science, 303, 73-76, 2004.

van der Werf, G. R., Randerson, J. T., Giglio, L., Collatz, G. J., Kasibhatla, P. S., and Arellano Jr., A. F.: Interannual variability in global biomass burning emissions from 1997 to 2004, Atmos. Chem. Phys., 6, 3423-3441, doi:10.5194/acp-6-3423-2006, 2006.

Wang, X., Piao, S., Ciais, P., Friedlingstein, P., Myneni, R. B., Cox, P., Heimann, M., Miller, J., Peng, S., Wang, T., Yang, H., and Chen, A.: A two-fold increase of carbon cycle sensitivity to tropical temperature variations, Nature, 506, 212-215, 2014.

Wang, Y., Li, M., and Shen, L. Accelerating carbon uptake in the Northern Hemisphere: evidence from the interhemispheric difference of atmospheric $\mathrm{CO}_{2}$ concentrations, Tellus B, 65, 20334, doi:10.3402/tellusb.v65i0.20334, 2013.

Wild, M.: Global dimming and brightening: A review, J. Geophys. Res., 114, D00D16, doi:10.1029/2008JD011470, 2009.

Xie, S. P. and Carton, J. A.: Tropical Atlantic variability: patterns, mechanisms, and impacts, in: Earth's Climate: The OceanAtmosphere Interaction, Geophys. Monogr. Ser., 147, edited by: Wang, C., Xie, S. P, and Carton, J. A., AGU, Washington, DC, 121-142, 2004.

Zaehle, S.: Terrestrial nitrogen-carbon cycle interactions at the global scale, Philos. T. R. Soc. B, 368, 20130125, doi:10.1098/rstb.2013.0125, 2013.

Zhao, M. and Running, S. W.: Drought-induced reduction in global terrestrial net primary production from 2000 through 2009, Science, 329, 940-943, 2010.

Zhu, Z., Bi, J., Pan, Y., Ganguly, S., Anav, A., Xu, L., Samanta, A., Piao, S., Nemani, R. R., and Myneni, R. B.: Global data sets of vegetation Leaf Area Index (LAI) 3g and Fraction Of Photosynthetically Active Radiation (FPAR) 3g derived from Global Inventory Modeling and Mapping Studies (GIMMS) Normalized Difference Vegetation Index (NDVI3g) for the period 1981 to 2011, Rem. Sens., 5, 927-948, 2013. 